\title{
EFFECTS OF LAND COVERS ON HYDRO-PHYSICAL SOIL CHARACTERISTICS IN SEMI-ARID ENVIRONMENTS: THE CASE OF GUMUSHANE-SIRAN, TURKEY
}

\author{
USta, A. - YILMAZ, M.* - KocAmanoĞLU, Y. O. - GenÇ, E. \\ Faculty of Forestry, Karadeniz Technical University, 61080 Trabzon, Turkey \\ *Corresponding author \\ e-mail: yilmaz61@ktu.edu.tr ; phone: +90-462-377-2854; ORCID: 0000-0002-9552-993X \\ (Received $4^{\text {th }}$ Aug 2018; accepted $4^{\text {th }}$ Oct 2018)
}

\begin{abstract}
Land degradation is already one of the major problems affecting the world. Land degradation by soil erosion is one of the most serious ecological problems and environmental issues in many sites of arid and semiarid regions. There has been an increasing concern regarding the semiarid highlands of Turkey that degradation of these ecosystems results in excessive soil erosion, ecosystem degradation, and loss of natural resources. This paper, therefore, explores the impact of land cover in a linkage to the soil erodibility indices and some soil properties of Koruluk (Gümüşhane-Turkey) dam watershed. Soil samples were taken from soil profiles opened in 78 sample pilots among the lands which border each other in the same altitude levels and same slopes on the andesite-basalt bedrock in the southern aspect group according to $0-10 \mathrm{~cm}$ and $10-20 \mathrm{~cm}$ depths. Sand, silt, clay, soil organic matter, dispersion ratio, erosion ratio, structural stability index, aggregate stability, clay dispersion ratio, field capacity, available water capacity, bulk density, total porosity, soil $\mathrm{pH}$ and electrical conductivity analyses were performed in soil samples. The results obtained about land cover were tested by variance analysis. The relationships between the selected soil characteristics were determined by correlation analysis. Degraded scotch pine forest soils were observed to be more susceptible to erosion compared to degraded oak forests and open space areas. Consequently, it was revealed that soils that developed from similar parent material in semiarid ecosystem and under all land covers were susceptible to erosion. The fact that the watershed supplies Koruluk dam built for irrigation water production makes these results quite significant. Agricultural activities are very important in the protection and continuity of the socio-economic situation of local people. The continuity of agricultural activities, in one respect, is associated with the availability of irrigation in this semi-arid region. Therefore, priority should be given to the necessary rehabilitation, planning and management studies in Koruluk dam watershed, and the results of this study should be considered.
\end{abstract}

Keywords: Koruluk dam, degraded forests, semi-arid, erodibility indices, soil properties

\section{Introduction}

Soil erosion is an ecological, environmental, economic, social and serious problem. This not only causes land degradation and reduction of soil fertility but also significantly affects the public health and sustainable development in rural areas (Tang, 2004; Zheng et al., 2004; Jing et al., 2005). Soil erosion is a natural process that continues depending on physiographic and climatic factors. However, it is the accelerated erosion that reduces soil fertility, decreases its quality, adversely affect water quality and management. Erosion can be accelerated through human activities. Surface mining, forestry, agriculture and construction are the major activities (Lal, 2001).

The trigger for accelerated erosion in arid and semi-arid areas is loss of vegetation cover. This exposes soils to wind and water erosion, loss of soils decreases the potential for vegetation production. The end result is a decrease in the carrying capacity of the rangeland and productivity of forests. Despite being in arid and semi-arid areas the 
erosion is largely a result of infrequent but heavy rainfall events. The erosion of soils exacerbates soil degradation. Soil quality decreases along with the erosion, especially structural units become weakened. In others, erosion may lead to decline in soil quality and set in motion the degradative trend. Soil erosion can be a manifestation of soil degradation because it involves physical removal of soil in a vertical and/or horizontal direction and degrades soil quality (Lal, 2001). Soil physical processes involve decline in soil structure leading to an increase in bulk density, decrease in total and macroporosity reduction in infiltration, increase in runoff, and exacerbation in erosion by water and wind.

Turkey is one of the countries that are most affected by erosion and are susceptible to land/soil degradation and drought because of its geomorphological structure, physiographic, edaphic and climatic characteristics. Sediment occurring in active erosion areas leads to major flooding, drainage and deposit losses in stream beds, baseagricultural lands, dams and reservoirs by accumulating. The reservoirs and dam built with big investments lose their function due to the runoffs and the soil material moved by the rivers and are in danger of being inactivate before their economic life. About 65 of the total area of Turkey has a semi-arid and arid characteristic (ÇEM, 2011). Drinking and potable water needs in arid and semi-arid regions are met by the dams and reservoirs. Arid and semiarid areas are considered fragile environments where vegetation cover is scarce and where soil erosion processes occur rapidly and severely after rainfall events fall in these areas. However, even under those conditions, the importance of native vegetation is very significant in the regulation of surface hydrological processes.

Land cover affects the occurrence and the intensity of runoff and soil erosion (Chen et al., 2001; Wei et al., 2007). Proper management of land cover patterns may greatly improve soil properties, leading to reduced soil erosion to the recommended threshold limits (Fu, 1989; Chen et al., 2003). Improved physical soil characteristics can also positively affect the establishment of vegetation (Kosmas et al., 2000). Land cover systems might lead to changes in a number of soil characteristics and soil erosion processes (Bao-hua et al., 2003; Costa et al., 2003).

Four dams and four reservoirs were established in Gümüshane region where the study was conducted. Koruluk dam watershed, one of these dams, has become susceptible to erosion and deterioration by the destruction of vegetation cover by local people as well as the effect of geomorphological and climatological characters. Being aware of erosion trends, physical and chemical characteristics of watershed soils is quite important for the rehabilitation works to be conducted in these areas and measures to be taken.

The aim of this study is to investigate the hydro-physical characteristics and some erosion trends of Koruluk Dam watershed soils in Gümüşhane-Şiran region which is located in semi-arid region in Turkey's Eastern Black Sea Region depending on land cover changes.

\section{Material and method}

\section{Study area}

Study area is located in Gümüşhane province in northeast of Turkey. Koruluk dam, which was built for irrigation, is located in the northern part of Gümüşhane-Şiran district and is $7 \mathrm{~km}$ away from there (Fig. 1). 


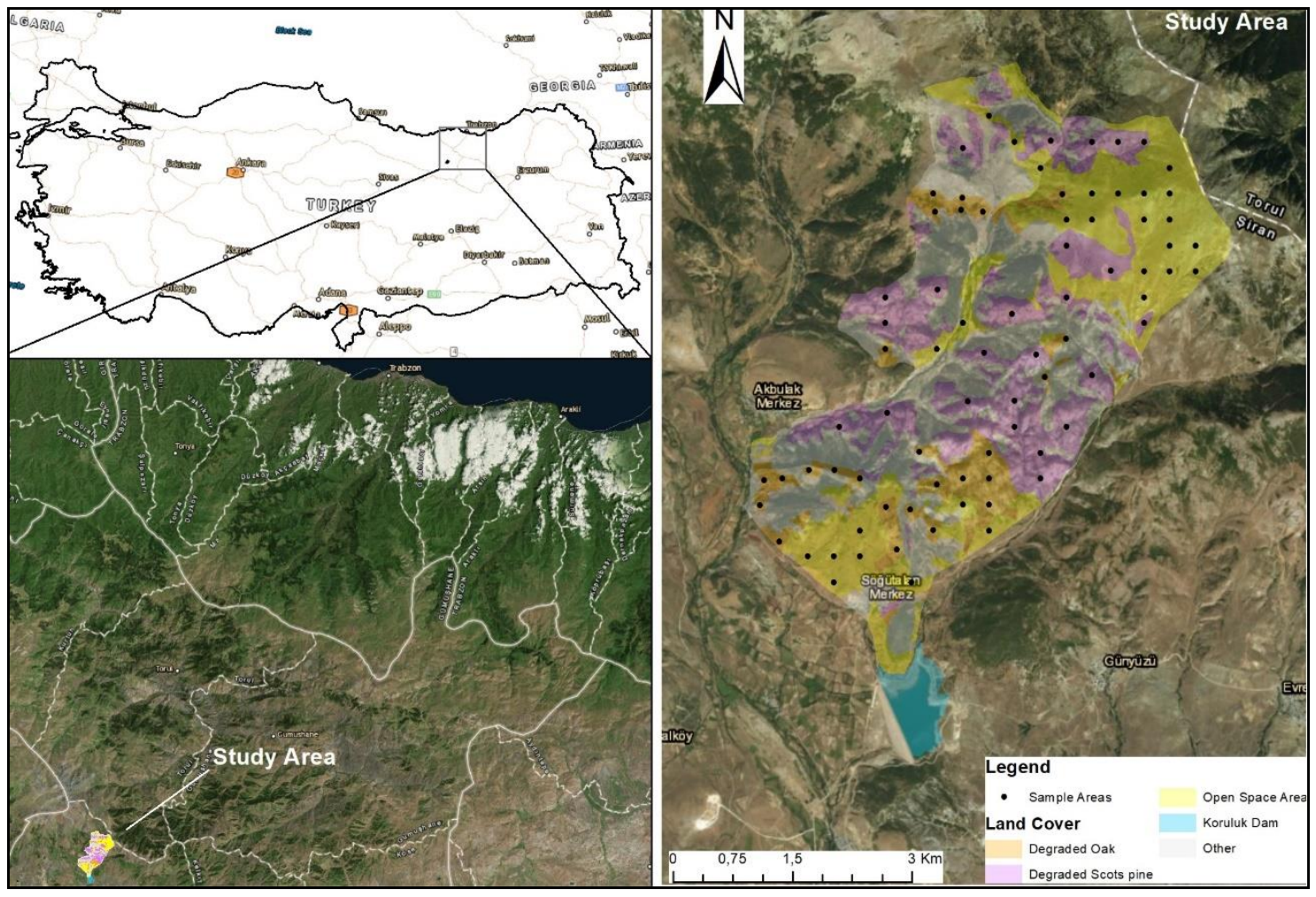

Figure 1. Location of study area

The construction of the dam was carried out between 1990-2005. The lake area is $0.7 \mathrm{~km}^{2}$ in normal water elevation. Total irrigation area of the dam used for for the irrigation of agricultural areas near the dam is 3447 ha. Erenkaya, Şiran, Çal, Söğütalan, Örenkale, Sarıca, Koyunbaba, Günbatur and Bilgili villages benefit from Koruluk dam fed by Ceviz stream for irrigation.

In the study area, eocene aged andesite-basalt volcanic rocks are surfaced (Baykal, 1952). The data of Kelkit meteorological station (1965-1989) close to Şiran district were used in determining the climatic type of the study area. According to Thornthwaite climate analysis, the study area has a climatic type which is "close to the continental climate with little or no excess water semi-arid at low temperature (microthermal) indicated by DC'2db'2" symbol". Some climate data according to Thornthwaite method were given in Table 1.

Table 1. Climate analysis according to Thornthwaite method (Thornthwaite, 1948)

\begin{tabular}{lccccccccccccc}
\hline & \multicolumn{110}{c}{ Climate data } & I & II & III & IV & V & VI & VII & VIII & IX & X & XI & XII & Annual \\
\hline Average temp, ${ }^{\circ} \mathrm{C}$ & -8.0 & -5.3 & 0.9 & 7.2 & 11.7 & 14.8 & 18.5 & 18.2 & 14.4 & 8.5 & 2.7 & -3.7 & 6.7 \\
Average precip, mm & 22.4 & 24.0 & 35.7 & 52.2 & 50.0 & 44.5 & 10.3 & 8.9 & 17.3 & 30.8 & 27.5 & 25.0 & 348.6 \\
Potential evapo, mm & 0.0 & 0.0 & 4.5 & 39.6 & 72.1 & 92.3 & 117.4 & 108.1 & 75.2 & 40.9 & 11.2 & 0.0 & 561.3 \\
Water defiency, mm & - & - & - & - & - & - & 77.0 & 99.2 & 57.9 & 10.1 & - & - & 244.3 \\
Water surplus, mm & - & - & 18.9 & 12.6 & - & - & - & - & - & - & - & - & 31.6 \\
\hline
\end{tabular}




\section{Soil sampling and analyses}

Sample pilots were taken from on soils developed from volcanic rocks and from south aspect. Average slopes and altitudes of the sample pilots are close to each other (Table 2).

Table 2. Geomorphological characteristics of the areas under different land cover

\begin{tabular}{lccc}
\hline & Degraded oak forest & Open space area & Degraded scotch pine forest \\
\hline Average slope (\%) & 31 & 35 & 38 \\
General aspect & South & South & South \\
Average altitude (m) & 1770 & 1820 & 1815 \\
Parent material & Andesite-basalt & Andesite-basalt & Andesite-basalt \\
\hline
\end{tabular}

Sample pilots in the study area were determined by the selection sampling method as 26, 28 and 24 pieces, respectively, including degraded oak forest, open space area and degraded scotch pine forest. Total of the 78 sample plots, 25 of them were received in Işık (2016). The soil was sampled at two different depths: 0-10 cm (surface layer) and 10-20 $\mathrm{cm}$ (subsurface layer). Statistical analyses and assessments were carried out for surface layer, subsurface layer and average of profile $(0-10 \mathrm{~cm}, 10-20 \mathrm{~cm}$ depths and $0-20 \mathrm{~cm}$ depth).

Particle size distribution (2-mm) and soil organic carbon $(0.5 \mathrm{~mm})$ were determined using disturbed soil samples using the Bouyoucos hydrometer method (Bouyoucos, 1962; Gülçur, 1974) and the modified Walkley-Black wet oxidation procedure, respectively. Soil organic matter (SOM) was calculated by multiplying soil organic carbon by 1.72 (Nelson and Sommers, 1982; Arp, 1999). Soil pH were measured using the procedures outlined by Arp (1999) and Page et al. (1982), for bulk density (BD) and total porosity (TP) by Blake and Hartge (1986) and Danielson and Sutherland (1986). Dispersion ratio (DR) was determined according to the methods described by Middleton (1930). The clay and silt fractions obtained by chemical dispersion were taken as total clay (TC) and total silt (TS), while water dispersible clay (WDC) was obtained as above except that no chemical dispersant was used. Colloid-moisture equivalent ratio (C-MER) and erosion ratio (ER) (Özhan, 2004), available water capacity (AWC) (Karaöz, 1989), aggregate stability (AS) (Le Bissonnais, 1996) and structure stability index (SSI) (Leo, 1963) were also determined.

\section{Statistical analyses}

Analyses of variance (ANOVA) were performed to determine the effects of land cover on the chemical and hydro-physical properties of the soil. Significant differences between variables were determined by Student-Newman-Keuls test. Correlation analysis was used to determine relationships between erodibility indices and hydrophysical properties of soils. Statistical analyses were performed using SPSS (2011).

\section{Results}

The change of average of the soil samples taken from two depth levels of soil profiles $(0-10 \mathrm{~cm}$ and $10-20 \mathrm{~cm}$ and $0-20 \mathrm{~cm}$ ) according to land cover was tested by 
analysis of variance. The selected soil characteristics of Koruluk dam watershed soils are statistically different compared to land cover $(\mathrm{p}<0.05$ and $\mathrm{p}<0.001)$ (Tables 3, 4, 5).

Table 3. Change of erodibility indices, physical and chemical properties of the topsoils under land covers $(0-10 \mathrm{~cm}$ soil depths)

\begin{tabular}{lccc}
\hline & \multicolumn{3}{c}{ Land covers } \\
\cline { 2 - 4 } & Degraded oak forest & Open space area & Degraded scotch pine forest \\
\hline Chemical soil properties & & & \\
SOM $(\%)$ & $2.38 \pm 1.34 \mathrm{~b}$ & $2.30 \pm 1.70 \mathrm{~b}$ & $1.40 \pm 1.21 \mathrm{a}$ \\
$\mathrm{pH}$ & $6.88 \pm 0.56 \mathrm{~b}$ & $6.18 \pm 0.18 \mathrm{a}$ & $6.31 \pm 0.53 \mathrm{a}$ \\
EC $(\mu \mathrm{s} / \mathrm{cm})$ & $64.5 \pm 46.8 \mathrm{~b}$ & $41.8 \pm 22.9 \mathrm{a}$ & $46.3 \pm 39.5 \mathrm{a}$ \\
\hline Physical soil properties & & & \\
BD & $1.19 \pm 0.12 \mathrm{a}$ & $1.19 \pm 0.09 \mathrm{a}$ & $1.20 \pm 0.08 \mathrm{a}$ \\
TP & $55.7 \pm 6.4 \mathrm{~b}$ & $57.1 \pm 5.3 \mathrm{~b}$ & $47.0 \pm 10.5 \mathrm{a}$ \\
Sand & $78.4 \pm 10.5 \mathrm{a}$ & $79.3 \pm 6.3 \mathrm{a}$ & $82.8 \pm 5.5 \mathrm{a}$ \\
Silt & $9.3 \pm 4.2 \mathrm{~b}$ & $10.7 \pm 2.9 \mathrm{~b}$ & $7.3 \pm 1.8 \mathrm{a}$ \\
Clay & $12.3 \pm 6.9 \mathrm{a}$ & $10.0 \pm 3.9 \mathrm{a}$ & $9.9 \pm 5.2 \mathrm{a}$ \\
FC & $20.4 \pm 3.7 \mathrm{a}$ & $24.5 \pm 7.9 \mathrm{~b}$ & $18.9 \pm 3.9 \mathrm{a}$ \\
AWC & $7.47 \pm 1.12 \mathrm{a}$ & $9.81 \pm 2.76 \mathrm{~b}$ & $8.21 \pm 2.06 \mathrm{a}$ \\
\hline Erodibility indices & & & \\
AS $(\%)$ & $52.2 \pm 16.7 \mathrm{~b}$ & $46.8 \pm 9.5 \mathrm{a}$ & $45.8 \pm 10.5 \mathrm{a}$ \\
SSI $(\%)$ & $14.52 \pm 10.3 \mathrm{~b}$ & $12.95 \pm 5.0 \mathrm{~b}$ & $9.78 \pm 3.1 \mathrm{a}$ \\
DR & $38.3 \pm 17.6 \mathrm{a}$ & $31.1 \pm 12.9 \mathrm{ab}$ & $43.4 \pm 10.7 \mathrm{bc}$ \\
C-MER & $0.56 \pm 0.29 \mathrm{~b}$ & $0.38 \pm 0.10 \mathrm{a}$ & $0.57 \pm 0.22 \mathrm{~b}$ \\
ER & $88.2 \pm 56.1 \mathrm{a}$ & $89.1 \pm 74.7 \mathrm{a}$ & $92.9 \pm 58.1 \mathrm{a}$ \\
WDC & $3.30 \pm 1.31 \mathrm{~b}$ & $1.61 \pm 1.38 \mathrm{a}$ & $2.92 \pm 1.59 \mathrm{~b}$ \\
\hline
\end{tabular}

Different letters indicate significant differences $(\mathrm{p}<0.05)$.

The soils collected from different land covers showed significant difference $(\mathrm{p}<0.001)$ with respect to average SOM content open space areas had the highest content of soil $(2.22 \%)$ followed by degraded oak forest $(2.01 \%)$, while the level of SOM in degraded scotch pine forest was very low (1.30\%) (Table 5).

There is no difference between land covers in terms of BD values. Degraded scotch pine forest soils have the highest average BD values $\left(1.18 \mathrm{~g} / \mathrm{cm}^{3}\right)$ in terms of BD average values (Table 5). Total porosity values of Koruluk dam watershed are statistically different according to land cover ( $p<0.001)$. The average AS value is minimum in degraded scotch pine forest soils and maximum in degraded oak forest soils. AS values are statistically different according to land cover $(\mathrm{p}<0.001)$. The highest silt content of soils presents in open space area soils (11.0\%) and is different from degraded oak forest and degraded scotch pine forest soils. While open space area and degraded oak forests are in the same group in the average sand contents of soils, the habitats dominated by degraded scotch pine forests are different with the highest values. The lowest average sand content was found in open space areas. There are significant differences in the soil fractions by percentage among land covers $(\mathrm{p}<0.05, \mathrm{p}<0.001)$. The clay content in environments in which degraded oak exists is higher than open 
space area and degraded scotch pine forests, degraded oak forest soils are similar with open space area soils and different from degraded scotch pine forest soils. DR from erodibility indices is greater than the limit value of 15 in soils under every three land covers. The highest DR values were found in degraded scotch pine forest soils and also the soils under this land cover are susceptible to erosion. However, degraded scotch pine forest soils are more susceptible to erosion. The study area soils vary according to land cover in terms of average DR values (Table 5).

ER values of soils are greater than the limit value of 10 in areas under all land cover, and soils were observed to be more susceptible to erosion in terms of this erosion index value. The highest average ER value was found in degraded oak forest soils (Table 5). No statistical difference was found according to land cover types in terms of the average ER values of soils. Although there was no difference in soils taken from the surface layer, ER values of subsurface layer were statistically different. All land covers are susceptible to erosion because its C-MER values are lower than the limit value of 1.5. C-MER values are statistically different; and open space area soils are present in two groups as separately with degraded scotch pine forest soils and degraded oak forest soils (Table 5). DR values are at the highest level in degraded scotch pine forest soils with the lowest clay+silt amounts (\%17.5), and at the lowest level in open space area soils with high clay+silt amounts (\%22.7) (Table 5).

Table 4. Change of erodibility indices, physical and chemical properties of the subsoils under land covers (10-20 cm depths)

\begin{tabular}{lccc}
\hline & \multicolumn{3}{c}{ Land covers } \\
\cline { 2 - 4 } & Degraded oak forest & Open space area & Degraded scotch pine forest \\
\hline Chemical soil properties & & & \\
SOM $(\%)$ & $1.51 \pm 0.67 \mathrm{a}$ & $2.13 \pm 1.30 \mathrm{~b}$ & $1.14 \pm 1.18 \mathrm{a}$ \\
pH & $6.77 \pm 0.28 \mathrm{~b}$ & $6.03 \pm 0.21 \mathrm{a}$ & $6.06 \pm 0.36 \mathrm{a}$ \\
EC $(\mu \mathrm{s} / \mathrm{cm})$ & $51.5 \pm 32.3 \mathrm{a}$ & $46.1 \pm 25.1 \mathrm{a}$ & $40.8 \pm 25.8 \mathrm{a}$ \\
\hline Physical soil properties & & & \\
BD $\left(\right.$ gr/cm $\left.{ }^{3}\right)$ & $1.15 \pm 0.15 \mathrm{a}$ & $1.10 \pm 0.08 \mathrm{a}$ & $1.16 \pm 0.05 \mathrm{a}$ \\
TP $(\%)$ & $52.6 \pm 9.5 \mathrm{a}$ & $60.7 \pm 4.1 \mathrm{~b}$ & $51.6 \pm 5.1 \mathrm{a}$ \\
Sand $(\%)$ & $78.2 \pm 15.6 \mathrm{a}$ & $75.0 \pm 6.7 \mathrm{a}$ & $82.1 \pm 2.9 \mathrm{a}$ \\
Silt $(\%)$ & $7.3 \pm 4.81 \mathrm{a}$ & $11.4 \pm 2.1 \mathrm{~b}$ & $8.7 \pm 3.1 \mathrm{a}$ \\
Clay $(\%)$ & $14.5 \pm 11.1 \mathrm{~b}$ & $13.5 \pm 5.2 \mathrm{~b}$ & $9.2 \pm 1.8 \mathrm{a}$ \\
FC $(\%)$ & $24.8 \pm 7.8 \mathrm{~b}$ & $26.9 \pm 11.2 \mathrm{~b}$ & $16.4 \pm 2.12 \mathrm{a}$ \\
AWC $(\%)$ & $8.05 \pm 2.3 \mathrm{a}$ & $9.46 \pm 2.6 \mathrm{a}$ & $8.22 \pm 0.82 \mathrm{a}$ \\
\hline Erodibility indices & & & \\
AS $(\%)$ & $60.9 \pm 13.4 \mathrm{c}$ & $52.5 \pm 7.0 \mathrm{~b}$ & $43.9 \pm 8.8 \mathrm{a}$ \\
SSI $(\%)$ & $15.95 \pm 15.0 \mathrm{~b}$ & $18.46 \pm 6.7 \mathrm{~b}$ & $11.67 \pm 2.3 \mathrm{a}$ \\
DR & $35.1 \pm 18.7 \mathrm{~b}$ & $25.8 \pm 9.9 \mathrm{a}$ & $42.7 \pm 10.5 \mathrm{~b}$ \\
C-MER & $0.61 \pm 0.42 \mathrm{a}$ & $0.52 \pm 0.20 \mathrm{a}$ & $0.60 \pm 0.07 \mathrm{a}$ \\
ER & $96.8 \pm 78.9 \mathrm{bc}$ & $58.2 \pm 26.2 \mathrm{a}$ & $73.1 \pm 23.9 \mathrm{ab}$ \\
WDC & $3.03 \pm 1.128 \mathrm{~b}$ & $1.96 \pm 1.32 \mathrm{a}$ & \\
\hline Differt & & \\
\hline
\end{tabular}

Different letters indicate significant differences $(\mathrm{p}<0.05)$. 
Table 5. Change of erodibility indices, physical and chemical properties of the soils under land covers (average of 0-20 cm depths)

\section{Land covers}

\begin{tabular}{lccc} 
& Degraded oak forest & Open space area & Degraded scotch pine forest \\
\hline Chemical soil properties & & & \\
SOM $(\%)$ & $2.01 \pm 1.81 \mathrm{~b}$ & $2.22 \pm 1.52 \mathrm{~b}$ & $1.30 \pm 1.19 \mathrm{a}$ \\
$\mathrm{pH}$ & $6.83 \pm 0.47 \mathrm{~b}$ & $6.11 \pm 0.21 \mathrm{a}$ & $6.20 \pm 0.42 \mathrm{a}$ \\
EC $(\mu \mathrm{s} / \mathrm{cm})$ & $58.9 \pm 41.4 \mathrm{~b}$ & $43.8 \pm 23.8 \mathrm{a}$ & $44.1 \pm 34.4 \mathrm{a}$ \\
\hline Physical soil properties & & & \\
BD $\left(\mathrm{gr} / \mathrm{cm}^{3}\right)$ & $1.17 \pm 0.12 \mathrm{a}$ & $1.14 \pm 0.09 \mathrm{a}$ & $1.18 \pm 0.07 \mathrm{a}$ \\
TP $(\%)$ & $54.5 \pm 5.8 \mathrm{c}$ & $58.9 \pm 7.0 \mathrm{~b}$ & $48.8 \pm 9.0 \mathrm{a}$ \\
Sand $(\%)$ & $78.3 \pm 12.8 \mathrm{a}$ & $77.4 \pm 6.8 \mathrm{a}$ & $82.5 \pm 4.6 \mathrm{~b}$ \\
Silt $(\%)$ & $8.5 \pm 4.5 \mathrm{a}$ & $11.0 \pm 2.6 \mathrm{~b}$ & $7.9 \pm 2.5 \mathrm{a}$ \\
Clay $(\%)$ & $13.2 \pm 8.9 \mathrm{bc}$ & $11.6 \pm 4.8 \mathrm{ab}$ & $9.6 \pm 4.2 \mathrm{a}$ \\
FC $(\%)$ & $22.3 \pm 6.22 \mathrm{c}$ & $25.6 \pm 9.5 \mathrm{~b}$ & $17.9 \pm 3.5 \mathrm{a}$ \\
AWC $(\%)$ & $7.72 \pm 1.77 \mathrm{a}$ & $9.65 \pm 2.71 \mathrm{~b}$ & $8.21 \pm 1.66 \mathrm{a}$ \\
\hline Erodibility indices & & & \\
AS $(\%)$ & $55.6 \pm 16.0 \mathrm{c}$ & $49.6 \pm 8.8 \mathrm{~b}$ & $45.0 \pm 9.8 \mathrm{a}$ \\
SSI $(\%)$ & $15.13 \pm 12.5 \mathrm{~b}$ & $15.45 \pm 6.8 \mathrm{~b}$ & $10.54 \pm 2.9 \mathrm{a}$ \\
DR & $37.1 \pm 17.9 \mathrm{~b}$ & $28.5 \pm 11.7 \mathrm{a}$ & $43.1 \pm 10.5 \mathrm{c}$ \\
C-MER & $0.57 \pm 0.34 \mathrm{~b}$ & $0.45 \pm 0.17 \mathrm{a}$ & $0.58 \pm 0.17 \mathrm{~b}$ \\
ER & $91.5 \pm 65.5 \mathrm{a}$ & $73.6 \pm 40.9 \mathrm{a}$ & $85.0 \pm 48.0 \mathrm{a}$ \\
WDC & $3.19 \pm 1.30 \mathrm{~b}$ & $1.78 \pm 1.36 \mathrm{a}$ & $2.84 \pm 1.45 \mathrm{~b}$ \\
\hline
\end{tabular}

Different letters indicate significant differences $(\mathrm{p}<0.05)$.

Relationships between some soil properties of $0-20 \mathrm{~cm}$ depths as the average of two depths $(0-20 \mathrm{~cm}, 10-20 \mathrm{~cm})$ and hydro-physical characteristics were tested by correlation analysis. In the correlation analysis carried out among soil properties selected in the study area which was susceptible to erosion, significant positive relationships were observed between SSI values and soil $\mathrm{pH}$, SOM, C-MER, silt and clay amounts, and significant negative relationships were observed between DR, ER, $\mathrm{BD}$ and sand amounts (Table 6).

Statistically significant and important relationships were found between the aggregate stabilities of the study area soils and some soil characteristics (Table 6). There are positive correlations between AS values of the soils and C-MER, SSI, pH, SOM, Clay and FC values; and there are negative correlations between DR, ER, BD, sand values.

\section{Discussion}

SOM values of open space areas and degraded oak forest top soils are higher than degraded scotch pine forest. SOM values in open space areas and degraded oak forests are statistically similar and different from degraded scotch pine forest soils $(\mathrm{p}<0.001)$. In degraded oak forests, while SOM values showed a decrease of approximately $37 \%$ in 
subsurface layer compared to surface layer, there is a decrease of $19 \%$ in degraded scotch pine forests. This decrease in the value of the SOM will reduce erosion resistance (Wu and Tiessen, 2002). DR, ER values of open space areas with high SOM content are lower, and SSI values are higher. The average FC and AWC are also high in open space area soils with high average of SOM content (Table 4). The easier weathering of meadow grass and annual plants in open space areas raised the SOM content compared to Oak and Scotch Pine litters. Increased SOM improves aggregation, water-holding capacity, nutrient-retention capacity and ion exchange capacity in soils. SOM is one of the most important factors that determine the soil structural properties (Abdollahi et al., 2014), an important criterion in terms of susceptibility to erosion (Boix-Fayos et al., 1998; Marti et al., 2001; Castro et al., 2002; Sarah, 2005; Le Bissonnais et al., 2007). The presence of SOM by $2 \%$ is an important threshold in terms of soil erosion due to AS (Oades, 1988; Cerda, 1996). Indeed, organic matter content of $60 \%$ of soil samples which is the subject of the research is lower than $2 \%$, and the aggregate stability of this land is relatively low. Therefore, it can be said that watershed soils are quite susceptible to erosion.

Table 6. The correlations between hydro-physical characteristics and soil properties (average of 0-20 cm depth)

\begin{tabular}{|c|c|c|c|c|c|c|c|}
\hline & Sand & Clay & Silt & SOM & FC & pH & EC \\
\hline AS (\%) & $-0.422 * *$ & $0.530 * *$ & 0.073 & $0.279 * *$ & $0.260 * *$ & $0.410 * *$ & $0.146^{*}$ \\
\hline Sand $(\%)$ & & $-0.946^{* *}$ & $-0.818^{* *}$ & $-0.198 *$ & $-0.321 * *$ & -0.052 & 0.270 \\
\hline Clay (\%) & & & $0.587 * *$ & 0.101 & $0.265^{* *}$ & $0.191 *$ & 0.360 \\
\hline Silt $(\%)$ & & & & $0.316^{* *}$ & $0.332 * *$ & $-0.208 *$ & $-0.145^{*}$ \\
\hline SOM $(\%)$ & & & & & $0.478 * *$ & 0.120 & $0.139 *$ \\
\hline $\mathrm{FC}(\%)$ & & & & & & -0.155 & -0.051 \\
\hline $\mathrm{pH}$ & & & & & & & $0.272 * *$ \\
\hline & DR & SSI & WDC & BD & TP & C-MER & ER \\
\hline $\mathrm{AS}(\%)$ & $-0.616 * *$ & $0.557 * *$ & 0.057 & $-0.620 * *$ & 0.084 & $0.542 * *$ & $-0.520 * *$ \\
\hline Sand $(\%)$ & $0.545^{* *}$ & $-0.933 * *$ & $-0.306^{* *}$ & $0.596^{* *}$ & $-0.162 *$ & $-0.799 * *$ & $0.681 * *$ \\
\hline Clay (\%) & $-0.500 * *$ & $0.891 * *$ & $0.411 * *$ & $-0.546^{* *}$ & $0.115^{*}$ & $0.886^{* *}$ & $-0.667 * *$ \\
\hline Silt (\%) & $-0.474 * *$ & $0.747 * *$ & $0.033 * *$ & $-0.518^{* *}$ & $0.202 * *$ & $0.448 * *$ & $-0.515^{* *}$ \\
\hline $\operatorname{SOM}(\%)$ & $-0.407 * *$ & $0.339 * *$ & $-0.255^{*}$ & $-0.502 * *$ & $0.312 * *$ & -0.088 & -0.127 \\
\hline $\mathrm{FC}(\%)$ & $-0.355 * *$ & $0.303 * *$ & $-0.172 *$ & $-0.443 * *$ & $0.296^{*}$ & $-0.201 *$ & 0.012 \\
\hline $\mathrm{pH}$ & $-0.181^{*}$ & 0.131 & $0.485 * *$ & -0.133 & -0.027 & $0.398 *$ & -0.042 \\
\hline $\mathrm{EC}$ & $-0.127 *$ & 0.085 & $-0.154 *$ & 0.046 & 0.083 & $0.180 * *$ & $-0.216 * *$ \\
\hline DR & & $-0.714^{* *}$ & $0.234^{*}$ & $0.625 * *$ & $-0.204 *$ & $-0.392 * *$ & $0.712 * *$ \\
\hline SSI & & & 0.137 & $-0.675^{* *}$ & $0.168 *$ & $0.771 * *$ & $-0.713 * *$ \\
\hline WDC & & & & $-0.210 *$ & -0.018 & $0.479 * *$ & $-0.162 *$ \\
\hline $\mathrm{BD}(\mathrm{gr} / \mathrm{lt})$ & & & & & $-0.368 * *$ & $-0.333 * *$ & $0.637 * *$ \\
\hline $\mathrm{TP}(\%)$ & & & & & & -0.189 & $-0.143^{*}$ \\
\hline C-MER & & & & & & & $-0.681 * *$ \\
\hline
\end{tabular}

AS: Aggregate stability, SOM: Soil organic matter, FC: Field capacity, EC: Electrical conductivity, DR: Dispersion ratio, SSI: Structural stability index, WDC: Water dispersible clay, BD: Bulk density TP: Total porosity, C-MER: Colloid-moisture equivalent ratio, **: Correlation is significant at the 0.01 level (2-tailed), *: Correlation is significant at the 0.05 level (2- tailed) 
Open space area and degraded scotch pine forest soils are similar in terms of soil reaction and more acidic than degraded oak forest soils. This situation may have emerged as a result of further leaching of open space area and degraded scotch pine forest soils. This will be understood when soil $\mathrm{pH}$ at surface layer and subsurface are compared (Tables 3, 4, and 5). Reasonably higher $\mathrm{pH}$ of the degraded scotch pine forests was primarily due to presence of base cations $\left(\mathrm{Ca}^{++}, \mathrm{Mg}^{++}, \mathrm{K}^{+}\right.$and $\left.\mathrm{Na}^{+}\right)$ associated in the soils. The fact that the oak litter had a slightly acid character and that the clay colloids in the soil (the average clay content is higher in degraded oak forest soils) adsorbed the base cations affected the high soil $\mathrm{pH}$ in degraded oak forests compared to other lands. Because the potential evaporation in the region is higher than the amount of rainfall, the water entering the soil during rainy season moves downwardly for a while (Table 1). With the start of the arid period, the deep water moves the dissolved salts to topsoil layers by evaporating and can increase the $\mathrm{pH}$ of the topsoil. This is even more evident in degraded oak forests where the average land slope and altitude are low. Acidity increases in the top layer in open space area soils as a result of root respiration of intense herbaceous plants. Soil $\mathrm{pH}$ is lower in degraded scotch pine forest soils due to acidic origin litter compared to degraded oak forest soils.

Although soil texture is not as effective as SOM on AS (Tisdall and Oades, 1982; Metzger et al., 1987; Roberson and Firestone, 1991; Canton et al., 2009), the clay fraction of soil is an important criterion on the aggregate strength (Balc1, 1996) and has a considerable impact on erosion trends. Clay content of the soils checks the structural stability of the soil (Gollany et al., 1991; Payne, 1992). In case of a decrease of structural stability and structural strength of the soil, soils undergo physical degradation (Sahani and Behera, 2001). The average clay content of Koruluk dam watershed are in degraded scotch pine forest, open space areas and degraded oak forest soils, respectively, including $9.6 \%, 11.6 \%$ and $13.2 \%$. It is reported that land cover is effective on the clay content (Okatan et al., 2010; Y1lmaz et al., 2015) and that the soils with clay content ranging between 9-30\% are more susceptible to erosion (Nkana and Tonye, 2003). The clay content of the majority of soils in the research area remains in these ranges (2.7-36.0\%), and soils under all land covers were found to be susceptible to erosion. All land covers showed more clay in the lower depth $(10-20 \mathrm{~cm})$ compared to the upper soil. While passing from top depth to lower depth, clay content increased in degraded oak forests by $20 \%$ and in open space areas by $35 \%$ (Tables 3 and 4 ). It decreased in degraded scotch pine forest by about $8 \%$. The increase in clay content in open space area and degraded oak forests and decrease in degraded scotch pine forest when going down from land cover on the same parent material and the same aspect to the lower depth levels in soil profiles can be explained in two ways. Firstly, litter decomposition is slow as the average altitude of degraded scotch pine forests is higher. In this case, lesser amount of water can enter the soil, and the movement of fine material in the soil could not take place. Second one is the decrease of decomposition reactions in the soil depending on the altitude as going down to soil depths. In open space areas and degraded oak forests, the presence of a layer that can transmit the soil by absorbing water that can reach on the soil especially in winter and spring seasons with abundant precipitation allowed the movement of clay from top soil to the lower soil in these areas, even if just a bit. Again, in the areas on these two land covers, SOM amount in the topsoil facilitated the movement of clay to sub soils by increasing soil permeability. The fact that the slope degrees of degraded oak forests and open space 
areas are less than degraded scotch pine forests is effective in increasing the amount of water that can enter into soil.

In semi-arid and arid regions with low degree of coverage of the vegetation such as the research area, soil erosion trends can significantly be affected by physiographictopographical features which are effective in the formation and development of soil, and the land cover. Within the scope of the study, the erosion trend values of soils developing under similar climatic conditions in the same parent material were found to be different. Probably, these differences resulted from the factors such as land cover type, altitude and land slope degree. These factors changed the other soil characteristics such as pore volume, BD and AS of the soil due to the mechanical composition of the soil. Pore size distribution and connectivity together with BD, aggregation and AS is important soil property that can be to a great extent influenced by the land degradation and soil erosion.

Degraded scotch pine forest soils had higher BD than the adjacent soils under degraded oak forests and open space areas for the average of two different depths. BD was generally higher in subsurface than surface soils (Table 5). This situation is more obvious in soil profiles taken from open space areas and degraded oak forests. A decrease occurred in BD with the accumulation of clay moved from top soil in sub soil horizons $(10-20 \mathrm{~cm})$. In degraded scotch pine forests, the BD remained approximately same as there was no significant change between the clay and silt content, amount of SOM, total porosity of the top soils with sub soils.

Many researchers reported that there are strong relationships between BD of soil and SOM content (Aşkın and Özdemir, 2003; Morisada et al., 2004; Leifeld et al., 2005; Perie and Ouimet, 2008). Curtis and Post (1964) stated a negatif correlation between SOM and BD. Sharma and Qahar (1989) and Gupta et al. (2010) determined the strongest correlation between BDs and SOM among the data attained from the analysis results. We obtained similar results with strong negative correlation $(r=-0.757$, $\mathrm{p}<0.001$ ) between SOM and BD of soil samples. In the research area, it was observed that DR, ER values were high, SSI, AS and C-MER values were lower in degraded scotch pine forest where SOM content was low, and BD was high. The increase in BD values increased the erosion sensitivity indices and decreased the endurance indices. Significant positive relationships were observed between BD values and DR and ER values as $\mathrm{r}=0.630, \mathrm{p}<0.001$ and $\mathrm{r}=638, \mathrm{p}<0.001$, respectively. Chaudhari et al. (2013) determined strong positive relationships in BD values and DR and ER values in their study $(\mathrm{r}=0.792, \mathrm{p}<0.001$ and $\mathrm{r}=0.663, \mathrm{p}<0.001)$. Along with the increase of BD of soil, SSI, AS, C-MER and TP values decreased, and this decrease was statistically significant (Table 6).

The total porosity of degraded scotch pine forest soils that was more susceptible to erosion remained the lowest. Water erosion and soil loss are expected to be less in open space area and degraded oak forest soils with high pore volume, and soil losses are expected to be more in degraded scotch pine forest soils with low pore volume. The low total porosity and low amounts of organic material of degraded scotch pine forest top soils $(0-10 \mathrm{~cm})$ may increase soil loss. The highest pore volume values were found in open space area soils where the average SOM is high. Dense rooting system of the open space areas grasses may account for the difference in TP of the 10-20 cm layer between the degraded scotch pine forest, degraded oak forest and open space areas soils. Vegetation increases SOM, TP, and reduces BD and soil erodibility (Igwe, 2003). In 
open space areas soils, high total porosity and amounts of SOM could reduce soil erosion by facilitating the entry of water into the soil with infiltration.

The main soil characteristics of soils affecting the aggregate stabilities are soil texture, clay mineralogy, SOM content, type and concentration of cations and sesquioxide contents (Le Bissonnais, 1996). However, general soil properties most closely correlated with soil AS are the contents of clay and SOM (Canasveras et al., 2010; Jozefaciuk and Czachor, 2014; Waruru et al., 2016). Clay particles are considered as cementing agents for aggregation because of their high specific surface area, cation exchange capacity, and consequently, high physical and chemical activity. SOM content can affect soil structure as well as soil AS various ways (Besalatpour et al., 2013). The topography and vegetation characteristics indirectly affect the aggregate stability (Canton et al., 2009). Furthermore, slope and aspect may influence the rate of weathering and erodibility of soils and thus soil aggregate stability (Bronick and Lal, 2005). The study area soils are susceptible to erosion under all land covers, and the erosion trends of open space area soils are lower in terms of DR, ER, WDC values. The average AS values were observed to be $49.6 \%$ in open space area soils, and the erosion trend values were higher in open space area soils and were $55.6 \%$ in degraded oak forest soils.

In other words, it is remarkable that the aggregate stability of degraded oak forest soils with higher erosion potential in terms of some parameters than open space area soils was found to be higher. It is thought that the fact that soil reaction (soil $\mathrm{pH}$ ) was higher in degraded oak forest soils influenced high AS values. The increase in soil reaction decreases the clay dispersion (Amezketa and Araqües, 1995; Lipiec et al., 2018), therefore, increases the aggregate stability. The main factors affecting the clay dispersion and clay clotting in the soil are the electrolyte concentration (EC), solution pH and sodium adsorption ratio (Shainberg and Letey, 1984; Suarez et al., 1984). Low electrolyte concentrations increase the clay dispersion and adversely affect the soil structure. It is well known that low electrolyte concentrations have adverse effects on hydraulic conductivity and infiltration ratio (Shainberg et al., 1987; Quirk, 1986; AbuSharar et al., 1987; Shainberg and Singer, 1990; Rengasamy and Olsson, 1991). The fact that the electrical conductivity values, a measure of the electrolyte concentration in soil solution, are maximum in degraded oak forest soils have an effect on high average aggregate stability values in these soils. When Tables 2, 3 and 4 are analyzed, it can be seen that the average SSI values of degraded oak forest soils with the highest average AS values are high.

The erosion trends values of soils vary depending on the soil's mechanical composition, infiltration capacity, the soil structure and the organic and chemical characteristics of the soil (Wishmeier and Smith, 1978; Canga, 1998). Texture is an important factor affecting erodibility values, but structure, SOM, and permeability also contribute (Mitchell and Bubenzer, 1980; Goldman et al., 1986). The change of sand, silt and clay fractions ratios forming the mechanical composition of the soils is very important because it changes the erosion trend values of the soils. High amount of sand and low amount of silt and clay increase the erosion trends of soils (Yilmaz et al., 2015). There are positive correlations between erosion trend values and the coarse fractions in the soil (Korkanç, 2003; Erol, 2004; Koiter et al., 2017). Soils under all land cover are susceptible to erosion in terms of DR, ER and C-MER values (Tables 3, 4 and 5). 
The clay+silt amounts of soils affect the erosion resistance since they are effective on SOM and water holding capacity. DR, one of the most important erodibility indicators, varies between 13.1 and 71.7. There are studies in which the DR values change between 13-69 (Igwe, 2003) and 26-95 (Korkanç, 2003).

Results of this study indicated that dispersion ratios varied according to the land cover $(\mathrm{p}<0.05)$. Soils of the open space area had a smaller and significant DR than rest of the soils developed from the other land covers, which had statistically similar values. On the other hand, having DR on greater than \%15, all land covers produced soils susceptible to water erosion.

In addition to these erodibility indices, SSI values are also used for the structural stability of soils. SSI values is an indicator of stable soil aggregates and thus higher SSI values, better will be the soil structure and higher will be the stable soil aggregates (Rudramurty et al., 2007). Structural stability has been used to evaluate the sensitivity of soils to erosion (Darboux and Le Bissonnais, 2006). The soils with the structural stability value of less than $40 \%$ are classified as strongly erodible soils, and the soils with higher structural stability value are classified as moderately erodible soils (Leo, 1963). Based on these erosion indices values, the study area soils are in the strongly erodible soils. SSI value is maximum in open space area soils by 15.43 and minimum in degraded scotch pine forest soils by 10.54. SSI values were found to be statistically different according to land covers. Open space area and degraded oak forest soils are similar, and degraded scotch pine forest soils are different (Tables 3, 4 and 5). It is well established that addition of SOM can not only reduce BD and increase water holding capacity and soil structure stability (Mikha et al., 2006). The fact that the structural stability index values of soils were found to be very low may be due to the low organic matter and clay content of the soil. SOM and clay content are the main abiotic binding agents in the formation and stabilization of aggregates (Tisdall and Oades, 1982; Chenu et al., 2000; Duchicela et al., 2012; Portella et al., 2012; Carrizo et al., 2015). The SOM of $60 \%$ of study area soils were found to be lower than $2 \%$. These low values in SOM may adversely affect the AS. Kay and Angers (Kay and Angers, 1999) stated that a minimum of $2 \%$ SOC was necessary to maintain SSI and observed that if SOC content was between $1.2-1.5 \%$, stability declined rapidly. In case of higher amounts of SOM, an increase can be expected in the SSI. Boix-Fayos et al. (2001) showed that a threshold of 3-3.5\% SOC had to be attained to achieve increases in AS; no effects on AS were observed in soils below this threshold.

The clay contents of the soil are considered to be more effective on the increase or decrease of structural stability index in soils with higher amount of organic matter than this threshold value. In the studies carried out by Y1lmaz et al. $(2015,2008)$, the structure stability indices of the soils with clay amount ranging from $8.5 \%$ to $15.7 \%$ varied between 14.5 and 25 , the structure stability indices of the soils with clay amount ranging from $40.6 \%$ to $47.8 \%$ varied between 41.0 and 50.9. It is reported that SSI values of the soils of different land covers with average amount of clay ranging from $17.8 \%$ to $22.9 \%$ vary between 22.3 and 29.3 (Y1lmaz et al., 2008).

\section{Conclusions}

The land cover has been destroyed in Koruluk dam watershed which was built to meet the irrigation water needs of the local community on Ceviz stream (GümüşhaneŞiran). It was determined that degraded oak forest, degraded scotch pine forests and 
open space areas were susceptible to erosion in sub watershed close to the dam reservoir.

In all study area, watershed lands are faced with effective erosion because they lack the protective vegetation cover. Active erosion in watershed lands threatens the economic life of dam reservoir and surrounding irrigation reservoirs. Protective vegetation cover should be created in areas close dam reservoir and residential areas by means of performing afforestation with the types such as rose hip and mayflower that will yield money for the local people and with oak in higher altitudes, and by grassing open spaces with appropriate types (such as Trifolium repense, Trifolium pratense, Dactylis glomerata, Festuca drymeja, Onobrychis sativa, Lolium perenne, Lotus corniculatus and Bromus inermis). If lands susceptible to erosion in the dam watershed are not restored with a continuous vegetation cover, dam reservoirs will complete their economic life in a shorter time due to the soil erosion that will occur. This study scientifically revealed that natural vegetation has significant effects on local water, soil conservation and ecological restoration management in a semi-arid ecosystem.

Further research is needed to determine the degree of improvement that vegetation can play an important role on soil porosity, bulk density, soil infiltration, soil structural properties (structural and aggregate stability) and soil erodibility indices. In this study area, the relationship between the function and the structure of the artificial vegetation should also be one of the focus points of future research.

\section{REFERENCES}

[1] Abdollahi, L., Schjønning, P., Elmholt, S., Munkholm, L. J. (2014): The effects of organic matter application and intensive tillage and traffic on soil structure formation and stability. - Soil and Tillage Research 136: 28-37.

[2] Abu-Sharar, T. M., Bingham, F. T., Rhoades, J. D. (1987): Stability of soil aggregates as affected by electrolyte concentration and composition. - Soil Science Society of America Journal 51: 309-314.

[3] Amezketa, E., Aragües, R. (1995): Flocculation-dispersion behaviour of arid-zone soil clays as affected by electrolyte concentration and composition. - Invest Agrar: Prod Prot Veg. 10(1): 101-112.

[4] Arp, P. A. (1999): Soils for Plant Growth, Field and Laboratory Manual. - Faculty of Forestry and Environmental Management, University of New Brunswick, Canada.

[5] Aşkın, T., Özdemir, N. (2003): Soil bulk density as related to soil particle size distribution and organic matter content. - Agriculture 9(2): 52-55.

[6] Balc1, A. N. (1996): Soil Conservation. - Istanbul University Faculty of Forestry, Publication no: 3947-439, Istanbul, Turkey (in Turkish).

[7] Bao-hua, Z., Yu-rong, H., Hong-yi, Z., Gen-wei, C. (2003): The features of soil aggregation and its eco-environmental effects under different subalpine forests on the east slope of Gongga Mountain, China. - Journal of Forestry Research 14(1): 80-82.

[8] Baykal, F. (1952): Geological investigations in Kelkit-Siran. - General Directorate of Mineral Research and Exploration, Compilation Report No. 2205, Ankara, Turkey (in Turkish).

[9] Besalatpour, A. A., Ayoubi, S., Hajabbasi, M. A., Mosaddeghi, M. R., Schulin, R. (2013): Estimating wet soil aggregate stability from easily available properties in a highly mountainous watershed. - Catena 111: 72-79.

[10] Blake, G. R., Hartge, K. H. (1986): Particle Density - In: Klute, A. (ed.). Methods of Soil Analysis. Part 1, 2nd edn. American Society of Agronomy, Inc. Soil Science Society of America, Madison, WI, pp. 377-381. 
[11] Boix-Fayos, C., Calvo-Cases, A., Imeson, A. C., Soriano-Soto, M. D., Tiemessen, I. R. (1998): Spatial and short-term temporal variations in runoff, soil aggregation and other soil properties along a Mediterranean climatological gradient. - Catena 33: 123-128.

[12] Boix-Fayos, C., Calvo-Cases, A., Imeson, A. C., Soriano-Soto, M. D. (2001): Influence of soil properties on the aggregation of some Mediterranean soils and the use of aggregate size and stability as land degradation indicators. - Catena 44: 47-67.

[13] Bouyoucos, G. J. (1962): Hydrometer method improved for making particle size analyses of soils. - Agronomy Journal 54: 464-465.

[14] Bronick, C. J., Lal, R. (2005) Soil structure and management: a review. - Geoderma 124: 3-22.

[15] Canasveras, J. C., Barron, V., Del Campillo, M. C., Torrent. J., Gomez. J. A. (2010): Estimation of aggregate stability indices in Mediterranean soils by diffuse reflectance spectroscopy. - Geoderma 158: 78-84.

[16] Canga, M. R. (1998): Soil Erosion and Conservation. - Faculty of Agriculture, Ankara University, Ankara.

[17] Canton, Y., Sole-Benet, A., Asensio, C., Chamizo, S., Puigdefabregas, J. (2009): Aggregate stability in range sandy loam soils: relationships with runoff and erosion.Catena 77: 192-199.

[18] Carrizo, M. E., Alesso, C. A., Cosentino, D., Imhoff, S. (2015): Aggregation agents and structural stability in soils with different texture and organic carbon contents. - Scientia Agricola 72(1): 75-82.

[19] Castro Filho, C., Lourenço, A., Guimaraes, M. D. F., Fonseca, I. C. B. (2002): Aggregate stability under different soil management systems in a red latosol in the state of Parana, Brazil. - Soil and Tillage Research 65(1): 45-51.

[20] ÇEM (2011): Arid and Semi-Arid Areas Management Workshop Final Declaration and Notifications. $\quad-\quad$ ÇEM, Nevşehir (in Turkish). http://www.cem.gov.tr/erozyon/Libraries/su/Kurak_ve_Yarı_Kurak_Alan_Yönetimi_Çal1 ştayı-nevşehir-Ürgüp.sflb.ashx (accessed 2018 March 29).

[21] Cerda, A. (1996): Soil aggregate stability in three Mediterranean environments. - Soil Technology 9(3): 133-140.

[22] Chaudhari, P. R., Ahire, D. V., Ahire, V. D., Chkravarty, M., Maity, S. (2013): Soil bulk density as related to soil texture, organic matter content and available total nutrients of Coimbatore soil. - International Journal of Scientific and Research Publications 3(2): 1-8.

[23] Chen, L., Wang, J., Fu, B., Qiu, Y. (2001): Land-use change in a small catchment of northern Loess Plateau, China. - Agriculture, Ecosystems \& Environment 86(2): 163172.

[24] Chen, L., Messing, I., Zhang, S., Fu, B., Ledin, S. (2003): Land use evaluation and scenario analysis towards sustainable planning on the Loess Plateau in China-case study in a small catchment. - Catena 54(1): 303-316.

[25] Chenu, C., Le Bissonnais, Y., Arrouays, D. (2000): Organic matter influence on clay wettability and soil aggregate stability. - Soil Science Society of America Journal 64(4): 1479-1486.

[26] Costa, M. H., Botta, A., Cardille, J. A. (2003): Effects of large-scale changes in land cover on the discharge of the Tocantins River, Southeastern Amazonia. - Journal of Hydrology 283(1): 206-217.

[27] Curtis, R. O., Post, B. W. (1964): Estimating bulk density from organic matter content in some vermont forest soils. - Soil Sci. Soc. Am. Proc. 28: 285-286.

[28] Danielson, R. N., Sutherland, P. L. (1986): Porosity. - In: Klute, A. (ed.) Methods of Soil Analysis. Part 1, 2nd edn. American Society of Agronomy, Inc. Soil Science Society of America, Madison, WI, pp. 443-460.

[29] Darboux, F., Le Bissonnais, Y. (2006): Changes in Structural Stability with Soil Surface Degradation. Consequences for Soil Erosion Processes. - In: EGU, European 
Geosciences Union (ed.) General Assembly 2006, Vol. 8. Copernicus Publications, Göttingen, Germany.

[30] Duchicela, J., Vogelsang, K. M., Schultz, P. A., Kaonongbua, W., Middleton, E. L., Bever, J. D. (2012): Non-native plants and soil microbes: potential contributors to the consistent reduction in soil aggregate stability caused by the disturbance of North American grasslands. - New Phytologist 196(1): 212-222.

[31] Erol, A. (2004): Effect of hydro-physical soil properties on soil formation factors in Kose Creek Watershed in Gumushane. - PhD Thesis. Istanbul University Graduate School of Natural \& Applied Sciences, Istanbul, Turkey (in Turkish).

[32] Fu, B. (1989): Soil erosion and its control in the Loess Plateau of China. - Soil Use and management 5(2): 76-82.

[33] Goldman, S. J., Jackson, K., Bursztynsky, T. A. (1986): Erosion and Sediment Control Handbook. - McGraw-Hill, New York, USA.

[34] Gollany, H. T., Schumacher, T. E., Evenson, P. D., Lindstrom, M. J., Lemme, G. D. (1991): Aggregate stability of an eroded and desurfaced Typic Argiustoll. - Soil Science Society of America Journal 55(3): 811-816.

[35] Gülçur, F. (1974): Physical and chemical soil analysis methods. - Istanbul University Faculty of Forestry Publications, No: 201, Istanbul, Turkey (in Turkish).

[36] Gupta, R. D., Arora, S., Gupta, G. D., Sumberia, N. M. (2010): Soil physical variability in relation to soil erodibility under different land uses in foothills of Siwaliks in NW India. - Tropical Ecology 51(2): 183-197.

[37] Igwe, C. A. (2003): Erodibility of soils of the upper rainforest zone, southeastern Nigeria. - Land Degradation \& Development 14(3): 323-334.

[38] Iş1k, S. (2016): Investigation of some hydro-physical properties in degraded forest areas in Gümüşhane-Şiran Location. Master's thesis. - Karadeniz Technical University, Trabzon, Turkey[In Turkish].

[39] Jing, K., Wang, W. Z., Zheng, F. L. (2005): Soil Erosion and Environment in China. Science Press, Beijing (in Chinese).

[40] Jozefaciuk, G., Czachor, H. (2014): Impact of organic matter, iron oxides, alumina, silica and drying on mechanical and water stability of artificial soil aggregates. Assessment of new method to study water stability. - Geoderma 221: 1-10.

[41] Karaöz, M. Ö. (1989): Methods of analysis for some soil chemical properties (pH, carbonate, salinity, organic matter, total nitrogen, available phosphorus). - Istanbul University, Faculty of Forestry. Series B 39: 64-82 (in Turkish).

[42] Kay, B. D., Angers, D. A. (1999): Soil Structure. - In: Sumner, M. E. (ed.) Handbook of Soil Science. CRC Press, Boca Raton, USA, pp. A-229-A-276.

[43] Koiter, A. J., Owens, P. N., Petticrew, E. L., Lobb, D. A. (2017): The role of soil surface properties on the particle size and carbon selectivity of interrill erosion in agricultural landscapes. - Catena 153: 194-206.

[44] Korkanç, S. Y. (2003): Land use problems and recommended solutions in the vicinity of Bartın (A case study of Iskalan Creek Watershed). - PhD Thesis, Istanbul University Graduate School of Natural \& Applied Sciences, Istanbul, Turkey (in Turkish).

[45] Kosmas, C., Gerontidis, S., Marathianou, M. (2000): The effect of land use change on soils and vegetation over various lithological formations on Lesvos (Greece). - Catena 40(1): 51-68.

[46] Lal, R. (2001): Soil degradation by erosion. - Land Degradation \& Development 12(6): 519-539.

[47] Le Bissonnais, Y. (1996): Aggregate stability and assessment of soil crustability and erodibility: I. Theory and methodology. - European Journal of Soil Science 47(4): 425437.

[48] Le Bissonnais, Y., Blavet, D., De Noni, G., Laurent, J. Y., Asseline, J., Chenu, C. (2007): Erodibility of Mediterranean vineyard soils: relevant aggregate stability methods and significant soil variables. - European Journal of Soil Science 58(1): 188-195. 
[49] Leifeld, J., Bassin, S., Fuhrer, J. (2005): Carbon stocks in Swiss agricultural soils predicted by land-use, soil characteristics, and altitude. - Agriculture, Ecosystems \& Environment 105(1): 255-266.

[50] Leo, W. M. (1963): A rapid method for estimating structural stability of soils. - Soil Science 96: 342-346.

[51] Lipiec, J., Czyż, E. A., Dexter, A. R., Siczek, A. (2018): Effects of soil deformation on clay dispersion in loess soil. - Soil and Tillage Research 184: 203-206.

[52] Martí, C., Badia, D., Buesa, M. A. (2001): Determinación de la estabilidad estructural de sue-los del altoaragón por tamizado en húmedo y lluvia simulada. - Edafología 8: 21-30 (in Spanish).

[53] Metzger, L., Levanon, D., Mingelgrin, U. (1987): The effect of sewage sludge on soil structural stability: microbiological aspects. - Soil Science Society of America Journal 51(2): 346-351.

[54] Middleton, H. E. (1930): Properties of soils which influence soil erosion No. 178. - US Dept. of Agriculture, Washington, DC.

[55] Mikha, M. M., Vigil, M. F., Liebig, M. A., Bowman, R. A., Mcconkey, B., Deibert, E. J., Pikul, J. L. (2006): Cropping system influences on soil chemical properties and soil quality in the Great Plains. - Renewable Agriculture and Food Systems 21(1): 26-35.

[56] Mitchell, J. K., Bubenzer, G. D. (1980): Soil Loss Estimation. - In: Kirkby, M. J., Morgan, R. P. C. (eds): Soil Erosion. John Wiley and Sons Ltd., London, pp. 17-62.

[57] Morisada, K., Ono, K., Kanomata, H. (2004): Organic carbon stock in forest soils in Japan. - Geoderma 119(1): 21-32.

[58] Nelson, D. W., Sommers, L. (1982): Total Carbon, Organic Carbon, and Organic Matter. - In: Page, A. L. et al. (eds.) Methods of Soil Analysis. Part 2. Chemical and Microbiological Properties, No. 9, American Society of Agronomy, Inc. Soil Science Society of America, Madison, WI, pp. 539-579.

[59] Nkana, J. C. V., Tonye, J. (2003): Assessment of certain soil properties related to different land-use systems in the Kaya watershed of the humid forest zone of Cameroon. - Land Degrad. Dev. 14: 57-67.

[60] Oades, J. M. (1988): The retention of organic matter in soils. - Biogeochemistry 5: 35-70.

[61] Okatan, A., Aydin, M., Usta, A., Y1lmaz, M. (2010): Effects of land use type on hydrophysical properties of soils in the Torul dam basin-Gumushane, Turkey. - Fresenius Environmental Bulletin 19(12b): 3230-3241.

[62] Özhan, S. (2004): Watershed Management. - Istanbul University Faculty of Forestry, Publication no: 482. Istanbul, Turkey (in Turkish).

[63] Page, A. L., Miller, R. H., Keeney, D. R. (1982): Methods of Soil Analysis. Part 2. Chemical and Microbiological Properties. - American Society of Agronomy, Inc. Soil Science Society of America, Madison, WI, Soil Science Society of America, Madison, Wisconsin.

[64] Payne, D. (1992): Estructura del suelo, laboreo y comportamiento mecánico. - In: Urbano, P., Rojo, C. (eds.) Condiciones del suelo y desarrollo de las plantas según Russell. Ediciones Mundi-Prensa, Madrid, pp. 395-430 (in Spanish).

[65] Perie, C., Ouimet, R. (2008): Organic carbon, organic matter and bulk density relationships in boreal forest soils. - Canadian Journal of Soil Science 88(3): 315-325.

[66] Portella, C. M. R., Guimaraes, M. D. F., Feller, C., Fonseca, I. C. D. B., Tavares Filho, J. (2012): Soil aggregation under different management systems. - Revista Brasileira de Ciencia do Solo 36(6): 1868-1877.

[67] Quirk, J. P. (1986): Soil permeability in relation to sodicity and salinity. - Phil. Trans. R. Soc. Lond. A. 316(1537): 297-317.

[68] Rengasamy, P., Olsson, K. A. (1991): Sodicity and soil structure. - Aust. J. Soil Res. 29: 935-932. 
[69] Roberson, E. B., Firestone, M. K. (1991): Cover crop management of polysaccharidemediated aggregation in an orchard soil. - Soil Science Society of America Journal 55(3): 734-739.

[70] Rudramurthy, H. V., Puttaiah, E. T., Gurumurthy, B. R. (2007): Structural stability index of soils under different land use systems in southern transitional zone of Karnataka. Karnataka J. Agric. Sci. 20(1): 126-127.

[71] Sahani, U., Behera, N. (2001): Impact of deforestation on soil physicochemical characteristics, microbial biomass and microbial activity of tropical soil. - Land Degradation \& Development 12(2): 93-105.

[72] Sarah, P. (2005): Soil aggregation response to long-and short-term differences in rainfall amount under arid and Mediterranean climate conditions. - Geomorphology 70(1): 1-11.

[73] Shainberg, I., Letey, J. (1984): Response of soils to sodic and saline conditions. California Agriculture 52(2): 1-57.

[74] Shainberg, I., Singer, M. J. (1990): Soil Responses to Saline and Sodic Conditions. Ch. 5. - In: Tanji, K. K. (ed.). Agricultural Salinity Assessment and Management. ASCE Manuals and Reports on Engineering Practice, No. 71, Am. Soc. Civil Eng., New York.

[75] Shainberg, I., Keren, R., Alperovitch, N., and Goldstein, D. (1987): Effect of exchangeable potassium on the hydraulic conductivity of smectite-sand mixtures. - Clays and Clay Min. 35: 305-310.

[76] Sharma, P. D., Qahar, A. Q. (1989): Characterisation of some Outer Himalayan protected and eroded forest soils. - Journal of the Indian Society of Soil Science 37: 113-120.

[77] SPSS (2011): Version 15.0. - SPSS, Chicago, IL.

[78] Suarez, D. L., Rhoades, J. D., Lavado, R., Grieve, C. M. (1984): Effect of pH on saturated hydraulic conductivity and soil dispersion. - Soil Sci. Soc. Am. J. 48: 50-55.

[79] Tang, K. L. (2004): Soil and water conservation in China. - Science Press, Beijing (in Chinese).

[80] Thornthwaite, C. W. (1948): An approach toward a rational classification of climate. Geographical Review 38(1): 55-94.

[81] Tisdall, J. M., Oades, J. (1982): Organic matter and water-stable aggregates in soils. European Journal of Soil Science 33(2): 141-163.

[82] Waruru, B. K., Shepherd, K. D., Ndegwa, G. M., Sila, A. M. (2016): Estimation of wet aggregation indices using soil properties and diffuse reflectance near infrared spectroscopy: An application of classification and regression tree analysis. - Biosystems Engineering 152: 148-164.

[83] Wei, W., Liding, C., Bojie, F., Zhilin, H., Dongping, W., Lida, G. (2007): The effect of land uses and rainfall regimes on runoff and soil erosion in the semi-arid loess hilly area. - China Journal of Hydrology 335(3-4): 247-258.

[84] Wischmeier, W. H., Smith, D. D. (1978): Predicting Rainfall Erosion Losses - A Guide to Conservation Planning. - USDA, Hyattsville, Maryland, USA.

[85] Wu, R., Tiessen, H. (2002): Effect of land use on soil degradation in alpine grassland soil, China. - Soil Science Society of America Journal 66(5): 1648-1655.

[86] Yilmaz, M., Yilmaz, F., Karagul, R., Altun, L. (2008): Changes in erodibility indices and some soil properties according to parent materials and land use regimes in erfelek dam creek watershed (Sinop, Turkey). - Fresenius Environmental Bulletin 17(12A): 20832090.

[87] Yilmaz, M., Usta, A., Çakir, G., Kahveci, S. N. I. (2015): The effects of land use type on soil erodibility indices in Galyan-Atasu dam watershed, Trabzon, NE Turkey. - Fresenius Environmental Bulletin 24(3B): 1082-1090.

[88] Zheng, F. L., Yang, Q. K., Wang, Z. L. (2004): Water erosion prediction model. Research of Soil and Water Conservation 11(4): 13-24 (in Chinese, with English abstract). 